\title{
SALICYLIC ACID INDUCED CYSTEINE PROTEASE ACTIVITY DURING PROGRAMMED CELL DEATH IN TOMATO PLANTS
}

\author{
Judit Kovács, Péter Poór, Ágnes SzePesi and Irma TARI* \\ Department of Plant Biology, University of Szeged, \\ Közép fasor 52, H-6726 Szeged, Hungary
}

(Received: December 13, 2015; accepted: January 18, 2016)

\begin{abstract}
The hypersensitive response (HR), a type of programmed cell death (PCD) during biotic stress is mediated by salicylic acid (SA). The aim of this work was to reveal the role of proteolysis and cysteine proteases in the execution of PCD in response of SA. Tomato plants were treated with sublethal $(0.1 \mathrm{mM})$ and lethal $(1 \mathrm{mM})$ SA concentrations through the root system. Treatment with $1 \mathrm{mM}$ SA increased the electrolyte leakage and proteolytic activity and reduced the total protein content of roots after $6 \mathrm{~h}$, while the proteolytic activity did not change in the leaves and in plants exposed to $0.1 \mathrm{mM} \mathrm{SA}$. The expression of the papain-type cysteine protease SlCYPI, the vacuolar processing enzyme SIVPE1 and the tomato metacaspase SIMCA1 was induced within the first three hours in the leaves and after $0.5 \mathrm{~h}$ in the roots in the presence of $1 \mathrm{mM} \mathrm{SA}$ but the transcript levels did not increase significantly at sublethal SA. The Bax inhibitor-1 (SlBI-1), an antiapoptotic gene was over-expressed in the roots after SA treatments and it proved to be transient in the presence of sublethal SA. Protease inhibitors, SIPI2 and SILTC were upregulated in the roots by sublethal SA but their expression remained low at $1 \mathrm{mM}$ SA concentration. It is concluded that in contrast to leaves the SA-induced PCD is associated with increased proteolytic activity in the root tissues resulting from a fast up-regulation of specific cysteine proteases and down-regulation of protease inhibitors.
\end{abstract}

Keywords: Bax Inhibitor 1 - cysteine protease - programmed cell death - salicylic acid - tomato

\section{INTRODUCTION}

Programmed cell death (PCD) is a genetically controlled process in plants in response to various developmental and environmental stimuli [26]. In case of phytopathogenic microorganism attack, a localized PCD, hypersensitive response (HR) can develop in the infected plant organs, thus dead cells form physical barriers against the infection [9]. HR is induced by oxidative burst elicited by the invading microorganisms and the PCD is associated with specific morphological and biochemical features, such as chromatin condensation, DNA fragmentation, shrinkage of protoplasts but due to the fast disintegration of membranes a part of cell content remains unchanged [21]. Proteolysis is also vital for the adaptation to abiotic or biotic stresses [27]. Proteases are highly regulated enzymes classified into four major classes: cysteine-, serine-,

*Corresponding author, e-mail address: tari@bio.u-szeged.hu 
aspartic acid- and metalloproteases [19]. Cysteine proteases, the cysteine-dependent aspartate-specific proteinases (caspases), have a key role in the animal proteolytic signaling cascade during apoptosis [28]. Plant cysteine proteases can be divided into three subfamilies: C1A subfamily (papain-like cysteine proteases, PLCP); C13 subfamily (legumains, e.g. vacuolar processing enzyme, VPE) and C14 subfamily (metacaspases, MCA) [25]. All cysteine protease subfamilies and protease inhibitors, the potent protein inhibitors of cysteine proteases in planta, play a crucial role in plant-pathogen interaction $[4,22,27]$. It was found that papain-like cysteine proteases were necessary to trigger the full HR against biotrophic pathogens [23].

Salicylic acid, a phenolic compound, plays an important role in the defense response of plants to abiotic and biotic stressors [5] by controlling gene expression, such as the expression of the cysteine protease gene (SAG12) or the PRla gene encoding a protein with antifungal activity $[13,14]$. Exogenous SA treatment can induce cell death by various signaling pathways, including reactive oxygen species (ROS). The SA-induced ROS accumulation was not controlled by ethylene in tomato cell suspension but it was accompanied by the increased activity of cysteine proteases [17]. Moreover, LeMCAl and gammaVPE genes were up-regulated during PCD and SA treatments [6;29] but the time and tissue-dependent expression of these protease genes were not detected.

Bax Inhibitor-1 (BI-1) is an ER-associated transmembrane protein, which is one of the most important cell death suppressors both in the animal and plant kingdom. Over-expressing BI-1 gene from Arabidopsis thaliana in tobacco BY-2 cell lines suppressed the $\mathrm{H}_{2} \mathrm{O}_{2}$ - or SA-mediated cell death suggesting that BI-1 is also essential for the inhibition of SA-induced PCD [10]. The strong up-regulation of BI-1 and cysteine protease inhibitors can inhibit PCD in plants [24], thus time-dependent regulation of the genes with pro- and anti-apoptotic function will be important to detect the effects of different SA concentrations in roots and leaves.

In this article, comparative physiological and molecular analysis of cysteine proteases and protease inhibitors were carried out in time course experiments after treatments with sublethal $(0.1 \mathrm{mM})$ and lethal $(1 \mathrm{mM})$ concentrations of SA in order to reveal their role in stress acclimation or in the development of cell death in tomato leaf and root tissues.

\section{MATERIALS AND METHODS}

\section{Plant material}

Tomato (Solanum lycopersicum L. cv. Rio Fuego) seeds were germinated at $26{ }^{\circ} \mathrm{C}$ for 3 days in the dark, and the seedlings were subsequently transferred to perlite for 2 weeks. Plants were grown hydroponically afterwards in controlled environment in a greenhouse $\left(200 \mu \mathrm{mol} \mathrm{m} \mathrm{m}^{-2} \mathrm{~s}^{-1}\right.$ photon flux density, 12/12 light/dark photoperiod, $25^{\circ} \mathrm{C}$ and $55-60 \%$ relative humidity) for 4 weeks [16]. Then two plants per pot, altogether 24 pots per treatment were maintained in fresh culture solution or were 
treated with $0.1 \mathrm{mM}$ or $1 \mathrm{mM}$ SA through the root system. These concentrations were chosen after preliminary experiments [16]. Samples were prepared in 3 replicates at 9 a.m. from the second, fully expanded young leaves and roots $0.5,1,2,3,6,24$ hours after the SA exposure.

\section{Electrolyte leakage measurement}

Disintegration of cell membranes was determined by the measurement of electrolyte leakage [18]. Tissue segments of the same size were collected on a filter paper and washed twice with $50 \mathrm{ml}$ of double distilled water and then $0.5 \mathrm{~g}$ of fresh tissues was incubated in $20 \mathrm{ml}$ of double distilled water at $25{ }^{\circ} \mathrm{C}$ for 2 hours. The conductivity in the bathing solution was determined (C1) with conductivity meter (Radelkis, Hungary). Then, the samples were heated at $95{ }^{\circ} \mathrm{C}$ for $40 \mathrm{~min}$ and the total conductivity (C2) of the cooled samples was measured. Relative electrolyte leakage (EL) was expressed as $\mathrm{EL}(\%)=(\mathrm{C} 1 / \mathrm{C} 2) \times 100$.

\section{Protein extraction}

Soluble proteins were extracted from $500 \mathrm{mg}$ root and shoot tissues with $1 \mathrm{ml} 50 \mathrm{mM}$ sodium-acetate buffer ( $\mathrm{pH}$ 6.1) containing $1 \mathrm{mM}$ dithiothreitol (DTT) at $4{ }^{\circ} \mathrm{C}$. The extract was centrifuged $\left(11,300 \mathrm{~g}, 4^{\circ} \mathrm{C}, 10 \mathrm{~min}\right)$, then the total protein content of supernatants was determined [2].

\section{Determination of protease activity by azocasein assay}

Azocasein was used as a non-specific substrate to measure the total proteolytic activity [15]. $50 \mu \mathrm{l}$ of protein extract, $0.3 \mathrm{ml}$ of $1 \%$ azocasein (w/v) and $650 \mu \mathrm{l}$ of potassium phosphate buffer ( $\mathrm{pH} 5.5$ ) were incubated at $37^{\circ} \mathrm{C}$ for $2 \mathrm{~h}$. The reaction was stopped by adding $300 \mu \mathrm{l}$ of $10 \%(\mathrm{w} / \mathrm{v})$ trichloroacetic acid (TCA) at $4{ }^{\circ} \mathrm{C}$ for $20 \mathrm{~min}$. After $20 \mathrm{~min}$ on ice the samples were centrifuged $\left(15,600 \mathrm{~g}, 4^{\circ} \mathrm{C}, 10 \mathrm{~min}\right)$, then the yellow colour was measured at $440 \mathrm{~nm}$ by spectrophotometer (KONTRON, Milano, Italy). One arbitrary unit (AU) of activity was defined as the amount of protein capable of increasing absorbance at $440 \mathrm{~nm}$ by 0.01 .

\section{$R N A$ purification and analyses of gene expression with quantitative real-time $R T-P C R$}

RNA was extracted from tomato roots and shoots samples by TRI reagent method based on [3]. After DNase treatment, cDNA was synthesized using MMLV reverse transcriptase [7]. Primers (Table 1) were designed using NCBI (http://www.ncbi.nlm. 
Table 1

Primer pairs used for qRT-PCR

\begin{tabular}{|c|c|c|c|c|}
\hline Name of tomato gene & $\begin{array}{c}\text { Abbreviations } \\
\text { used } \\
\text { in the article }\end{array}$ & $\begin{array}{l}\text { Tomato genome } \\
\text { locus identifier }\end{array}$ & & Primer pair sequences $\left(5^{\prime}-3^{\prime}\right)$ \\
\hline \multirow{2}{*}{ Elongation factor- $1 \mathrm{a}$} & \multirow{2}{*}{ SlEFla } & \multirow{2}{*}{ XM_004240531.2 } & $\mathrm{F}:$ & GGAACTTGAGAAGGAGCCTAAG \\
\hline & & & R: & CAACACCAACAGCAACAGTCT \\
\hline \multirow{2}{*}{$\begin{array}{l}\text { Papain-like cysteine } \\
\text { protease } 1\end{array}$} & \multirow{2}{*}{ SlCYP1 } & \multirow{2}{*}{ AJ003137.1 } & F: & ACTGGGGAGAGAACGGCTAC \\
\hline & & & $\mathrm{R}:$ & CGGGTTTAGGAGGATTTGGT \\
\hline \multirow{2}{*}{$\begin{array}{l}\text { Vacuolar processing } \\
\text { enzyme }\end{array}$} & \multirow{2}{*}{ SIVPE1 } & \multirow{2}{*}{ XM_004253050.2 } & F: & TTTTCATCCTCGTCGGAATC \\
\hline & & & $\mathrm{R}:$ & GAGTCATCTGCGTCATCGAA \\
\hline \multirow{2}{*}{ Metacaspase 1} & \multirow{2}{*}{ SlMCA1 } & \multirow{2}{*}{ NM_001279269.1 } & F: & CCGTGAGGAAGAAGAGGAGA \\
\hline & & & $\mathrm{R}:$ & GAGTGGAAAGAGGCAAGGACT \\
\hline \multirow{2}{*}{ Bax Inhibitor-1 } & \multirow{2}{*}{ SlBII } & \multirow{2}{*}{ NM_001247521.2 } & F: & CTCAAAAACTTCCGCCAGAT \\
\hline & & & $\mathrm{R}:$ & GCCACTAAAGCACAGCATAGC \\
\hline \multirow{2}{*}{ Protease inhibitor II } & \multirow{2}{*}{ SlPI2 } & \multirow{2}{*}{ AB110700.1 } & F: & ATTCAAGATGTCCCCGTTCA \\
\hline & & & $\mathrm{R}:$ & AGCAACCCTTGTACCCTGTG \\
\hline \multirow{2}{*}{ Cystatin } & \multirow{2}{*}{ SlLTC } & \multirow{2}{*}{ AF198388.1 } & F: & GACGAGATCCATAGCCTTGC \\
\hline & & & $\mathrm{R}:$ & TCAAGAGTGAGGTGGTGCAG \\
\hline
\end{tabular}

nih.gov/) and Primer3 software (http://frodo.wi.mit.edu/) and were synthesized in the Nucleic Acid Synthesis Laboratory, Biological Research Center (Szeged, Hungary). The expression rate of genes was monitored by quantitative real-time PCR (Biorad, Hercules CA, USA) using SYBR green probes [7]. Each reaction was repeated at least three times. qRT-PCR was initiated with denaturation at $95{ }^{\circ} \mathrm{C}$ for $10 \mathrm{~min}$ followed by 41 cycles of denaturation at $95{ }^{\circ} \mathrm{C}$ for $15 \mathrm{~s}$ and annealing extension at $60{ }^{\circ} \mathrm{C}$ for $1 \mathrm{~min}$. Data analysis was performed using Opticon monitor software (Biorad, Hercules CA, USA). To determine the specificity of the reaction, a melting curve analysis of the product was performed immediately after the final PCR cycle by increasing the temperature from 55 to $90{ }^{\circ} \mathrm{C}(0.21 \mathrm{C} \mathrm{s} 1)$. Data were normalized using the tomato elongation factor $\alpha$ subunit $(S I E F-1 \alpha)$, which showed constant expression levels in the tissues. Data were calculated with $2^{(-\Delta \Delta C T)}$ method [12].

\section{Statistical analysis}

Data presented are mean values of a representative experiment $(n=3)$ resulted from 3 independent biological repetitions. Statistical analysis was carried out with Sigma plot 11.0 software (Systat Software Inc., Erkrath, Germany). After ANOVA a comparison of means was carried out by Duncan's multiple range test and differences were considered significant if $\mathrm{P} \leq 0.05$. 


\section{RESULTS}

To investigate the role of salicylic acid (SA) in plant PCD, the membrane integrity of root and leaf tissues was measured after the treatment with sublethal $(0.1 \mathrm{mM})$ and lethal $(1 \mathrm{mM})$ concentration of SA by the leakage of electrolytes from the tissues (EL) (Fig. 1B, C). $1 \mathrm{mM} \mathrm{SA}$ increased the EL significantly after 6 hours both in roots and leaves of tomato plants (Fig. 1C). However, the membrane integrity was maintained after $0.1 \mathrm{mM} \mathrm{SA}$ treatment in the first $24 \mathrm{~h}$ (Fig. 1B).

It was found that the protein content was much higher in the leaves than in the roots and it remained constant after treatment with $0.1 \mathrm{mM} \mathrm{SA}$ (Fig. 2A) but it began to decrease in the roots from the 6th hour after treatment with $1 \mathrm{mM} \mathrm{SA}$ (Fig. 2B). In contrast to the protein level, the proteolytic activity was significantly higher in the root than in the leaf tissues (Fig. 2D-F). In parallel with the reduced protein content, total protease activity increased significantly after 6 hours in the roots, while there were no changes in the leaves of plants exposed to $1 \mathrm{mM} \mathrm{SA}$ (Fig. 2F). The effect of
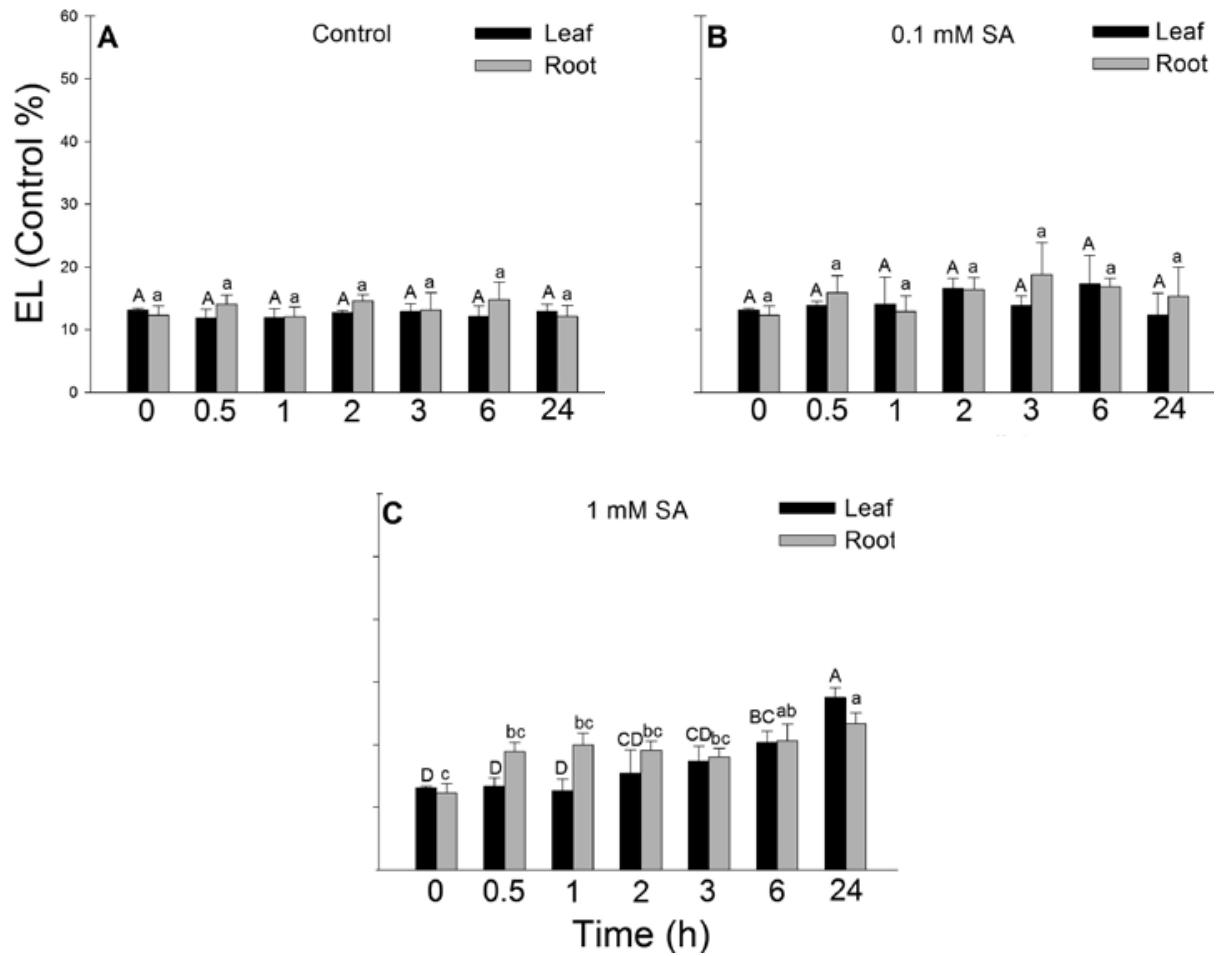

Fig. 1. The loss of plasma membrane integrity in tomato leaves and roots was determined by electrolyte leakage (EL) induced by $0.1 \mathrm{mM}$ (B) and $1 \mathrm{mM}$ (C) SA applied for 24 hours. Means $\pm \mathrm{SE}, \mathrm{n}=3$. Bars with different letters are significantly different at the 0.05 level (Duncan's multiple range test). The tests were performed separately for leaf and root samples and are indicated by capitals (leaf) and by lowercase letters (root), respectively 


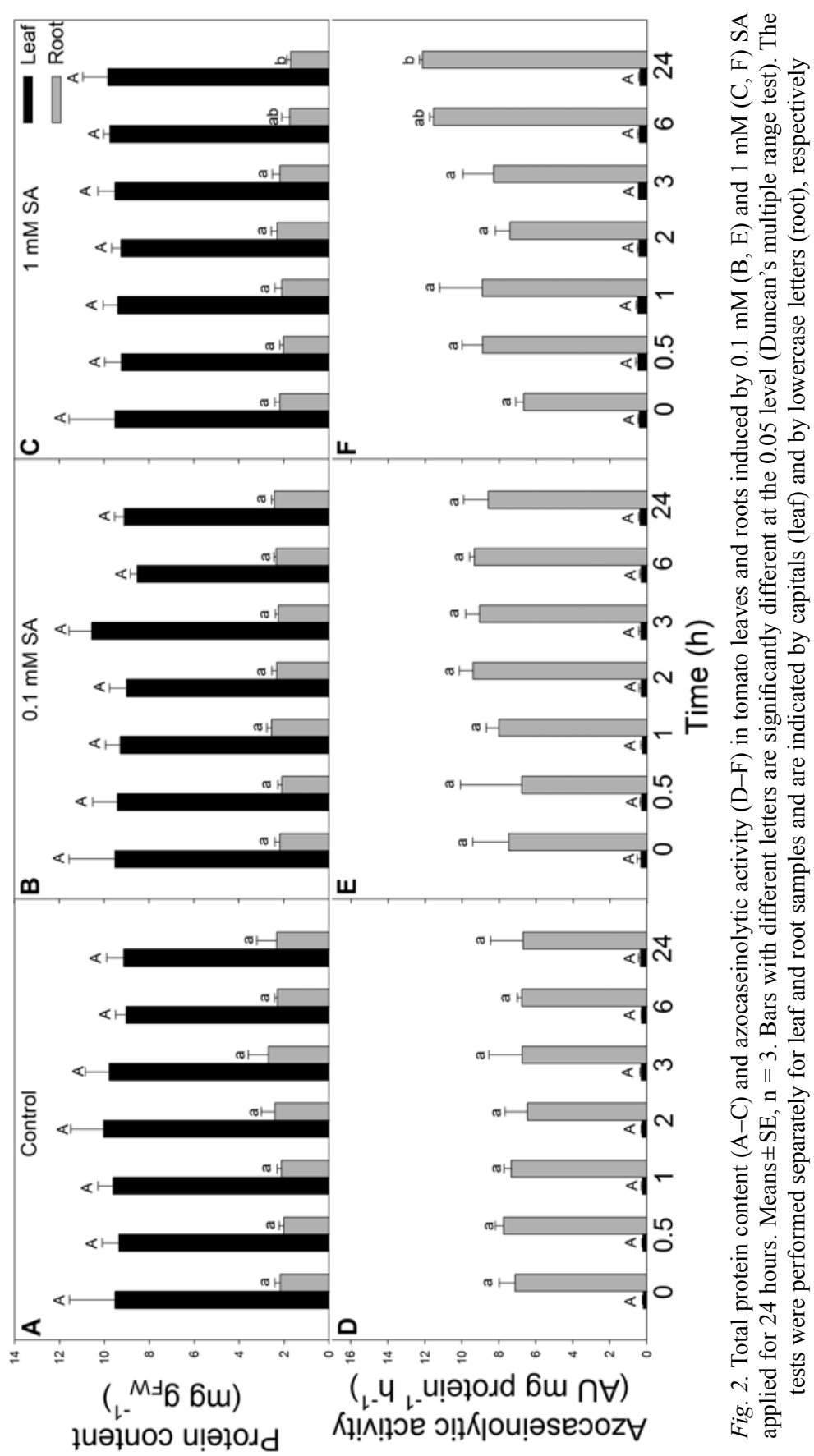


sublethal, $0.1 \mathrm{mM} \mathrm{SA}$ on proteolytic activity was not significant during the experiment (Fig. 2E).

The expression levels of specific genes involved in cell death program and proteolysis were analyzed by qRT-PCR in plants exposed to sublethal and lethal SA concentrations. The expression of SlCYP1, the papain-like cysteine protease gene increased slightly after $0.1 \mathrm{mM} \mathrm{SA}$ treatment but its transcript accumulation was significant only in the roots after $1 \mathrm{mM} \mathrm{SA}$ treatment. SlCYP1 expression increased significantly in the leaves of the same plants in the first and second hours (Fig. 3). The

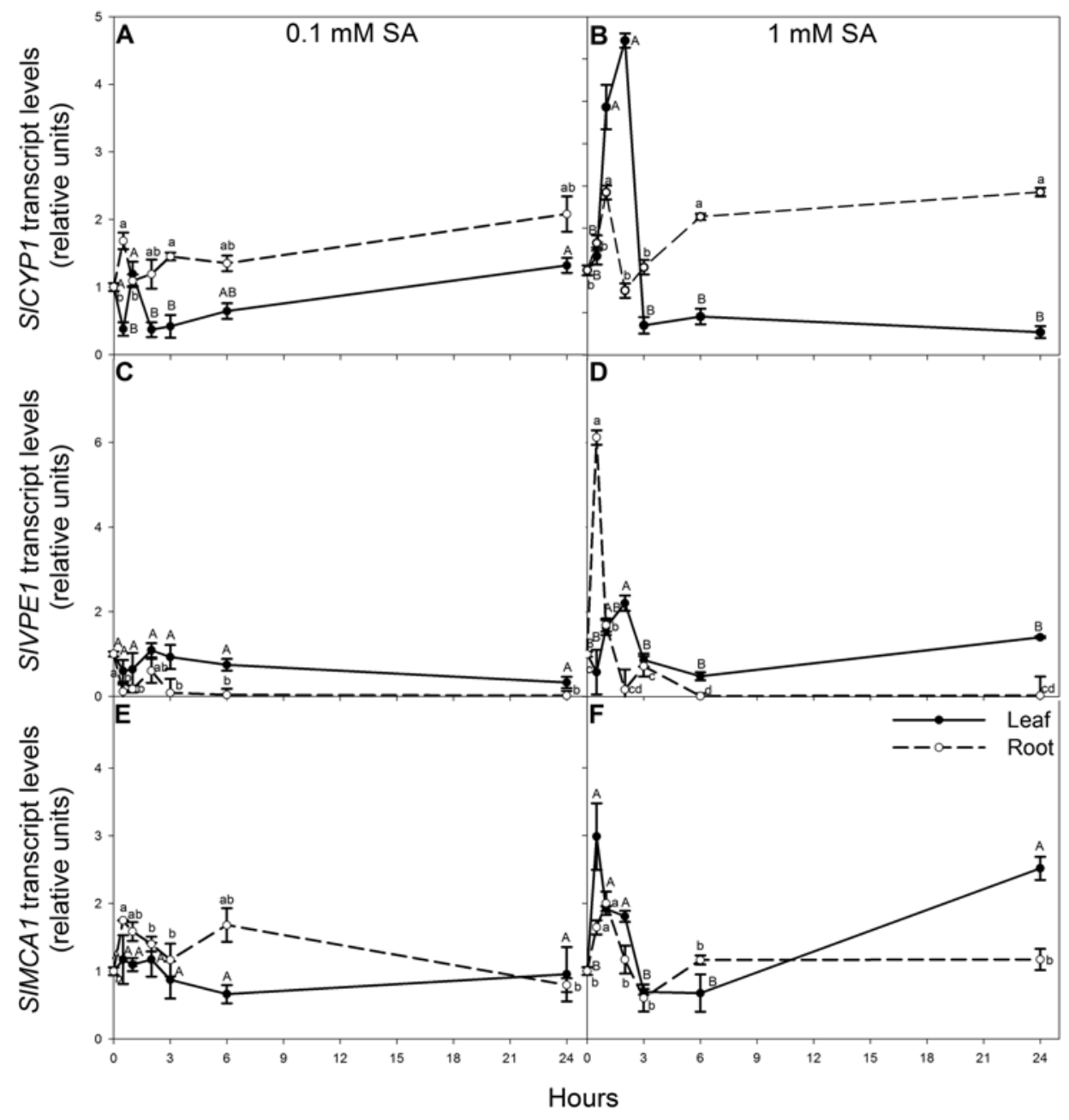

Fig. 3. Relative transcript levels of cysteine protease genes (SICYP1, SIMCA1, SlVPE1) induced by $0.1 \mathrm{mM}(\mathrm{A}, \mathrm{C}, \mathrm{E})$ and $1 \mathrm{mM}(\mathrm{B}, \mathrm{D}, \mathrm{F}) \mathrm{SA}$ in tomato leaves and roots. Data were normalized to their respective controls. Means $\pm \mathrm{SE}, \mathrm{n}=3$. Bars with different letters are significantly different at 0.05 level (Duncan's multiple range test; ns: not significant). The tests were performed separately for leaf and root samples and are indicated by capitals (leaf) and by lowercase letters (root), respectively 
gene encoding vacuolar processing enzyme, SIVPE1 was strongly up-regulated in the roots during the first hour and a little bit later in the leaves by the treatment with $1 \mathrm{mM}$ SA but its expression remained at control level in plants exposed to $0.1 \mathrm{mM}$ SA. Similar changes can be observed in the case of the metacaspase gene, SIMCA1 expression, which increased after treatment with the lethal concentration of SA in the roots and leaves in the first hour of the SA exposure and in the leaves after 24 h-long treatment but it exhibited only smaller changes in plants exposed to sublethal stress (Fig. 3).

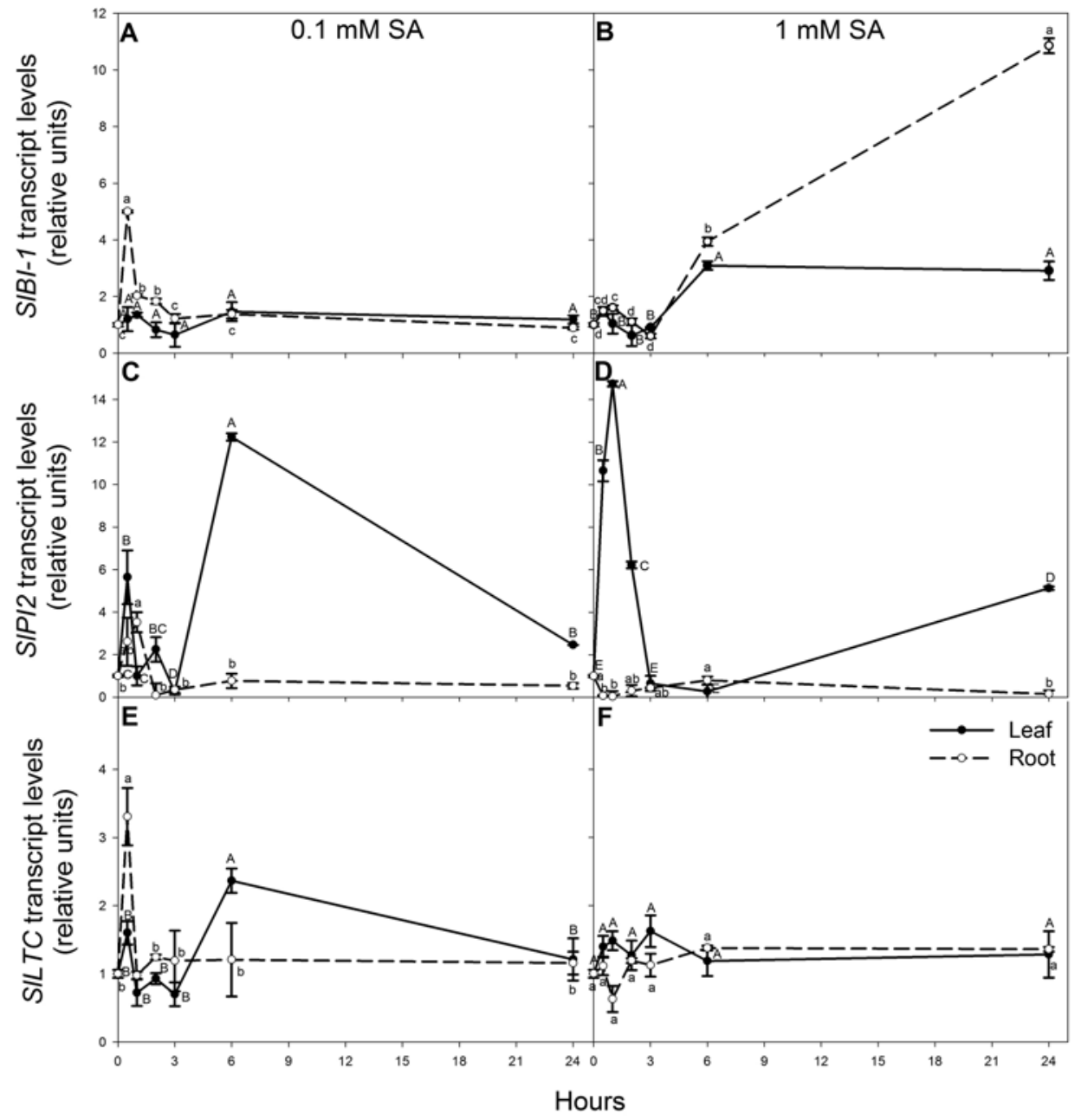

Fig. 4. Relative transcript levels of SIBI-1, SIPI2, SILTC genes induced by $0.1 \mathrm{mM}$ (A, C, E) and $1 \mathrm{mM}$ $(\mathrm{B}, \mathrm{D}, \mathrm{F}) \mathrm{SA}$ in tomato leaves and roots. Data were normalized to their respective controls. Means $\pm \mathrm{SE}$, $n=3$. Bars with different letters are significantly different at the 0.05 level (Duncan's multiple range test). The tests were performed separately for leaf and root samples and are indicated by capitals (leaf) and by lowercase letters (root), respectively 
Besides the analysis of cysteine protease genes, the genes having a role in the inhibition of plant PCD were also investigated. The expression of SlBI-1 coding for the antiapoptotic Bax Inhibitor-1 increased significantly in the presence of the lethal concentration of SA both in the leaf and root tissues after 6 hours, while it was transiently increased in the roots by the treatment with $0.1 \mathrm{mM} \mathrm{SA}$ in the first hour (Fig. 4A, B). Protein products of SIPI2 and SILTC genes can inhibit protease activity and thus suppress cell death in plants. In the leaves SIPI2 encoding a Protease Inhibitor-2 protein was up-regulated and exhibited two maxima with different kinetics at both SA concentrations (Fig. 4C, D). However, in the root tissues SIPI2 was up-regulated only after $0.1 \mathrm{mM} \mathrm{SA}$ treatment (Fig. 4C). The expression of SILTC encoding a cysteine protease inhibitor cystatin did not change after the treatment with $1 \mathrm{mM}$ SA but it increased with different kinetics in the roots and in the leaves at sublethal SA concentration (Fig. 4E, F).

\section{DISCUSSION}

A widespread feature of plant resistance to biotrophic microorganism is the HR, which is characterized by the formation of necrotic lesions at the infection site. HR is the rapid formation of ROS and is controlled by the accumulation of SA in the host cells surrounding microorganisms. Following this local response, a systemic acquired resistance (SAR) will develop in tissues distal from the infected site. It was found that the cell death can be initiated by a rapid accumulation of ROS and nitric oxide (NO) by lethal doses of SA [17] but the role of various cell death promoting or inhibiting factors, such as the activation cysteine proteases or proteinase inhibitors along with that of the Bax Inhibitor-1 has not yet been revealed in details.

Our experiments demonstrated that in short time scale the proteolytic activity increased only in the root tissues which received high, $1 \mathrm{mM}$ exogenous SA treatment. In the leaves of the same plants SA could be transported to the shoot and resulted in the disintegration of plasmamembrane as it could be seen from the enhanced EL, but the proteolytic activity did not change. The participation of two cysteine proteases, SICYP 1 and SIVPE 1 has also been confirmed in $1 \mathrm{mM} \mathrm{SA}$-induced PCD in tomato roots. In contrast to plants exposed to sublethal SA treatment, their expression was significantly increased in the roots immediately after application of high SA concentration. This was not accompanied by the induction of the protease inhibitor genes SLPI2 and SILTC. It is in accordance with the findings of other authors who found that the induction of protease-encoding genes and a concomitant repression of cystatin-encoding genes may trigger proteolysis in stressed [1] and senescing tissues [20]. In contrast to these findings, appropriate cysteine protease inhibitor/cys protease balance contributes to the preservation of proteins during stress conditions induced by low concentration of SA. Cysteine proteases (SlCYP 1, SlVPE1 and SLMCA1) were also induced in the leaves but in contrast to roots it proved to be transient in the case of SlCYPl, and it was not accompanied at this phase with increased total protein degradation. 
BI-1 proteins are also involved in plant stress response and the expression of BI-1 gene is usually associated with the senescence of plant organs. It was found that BI-1 resulted in attenuation of cell death induced by biotic and abiotic stresses [8]. In our system the $S l B I-1$ gene was up-regulated transiently but very significantly in the roots but not in the leaves under sublethal stress evoked by $0.1 \mathrm{mM} \mathrm{SA}$. In accordance with previous findings $[10,16]$ high SA concentration induced a substantial increase in the expression of SIBI-1 both in root and in leaf tissues. However, this enhancement does not mitigate the effect of SA on PCD induction. Surprisingly, mammalian BI-1 itself can act as a $\mathrm{Ca}^{2+} / \mathrm{H}^{+}$antiporter in the ER membrane under acidic $\mathrm{pH}$ conditions, which in human cells resulted in the activation of Bax-dependent apoptosis pathway [11]. Since the activation of VPE1, the plant vacuolar enzyme occurs after tonoplast disruption, which also causes a dramatic acidification of the cytoplasm (from $\sim 7.3$ to $\sim 5-6$ ), the putative promoting role of plant BI-1 in the cell death program during the terminal phase of plant PCD has to be taken into consideration.

Cysteine proteases that interact with cystatins along with Bax Inhibitor-1 may be good objectives to reveal the mechanism of SA-induced cell death.

\section{ACKNOWLEDGEMENTS}

This work was supported by grants from the Hungarian National Scientific Research Foundation (OTKA K101243 and OTKA PD 112855). This research was also supported by the European Union and the State of Hungary, co-financed by the European Social Fund in the framework of TÁMOP 4.2.4. A/2-11-1-20120001 'National Excellence Program' and by the HUSRB/120/221/173 PLANTTRAIN IPA Fund. No conflict of interest is declared.

\section{REFERENCES}

1. Benchabane, M., Schlüter, U., Vorster, J., Goulet, M.-C., Michoud, D. (2010) Plant cystatins. Biochemie 92, 1657-1666.

2. Bradford, M. M. (1976) A rapid and sensitive method for the quantitation of microgram quantities of protein utilizing the principle of protein-dye binding. Anal. Biochem. 72, 248-254.

3. Chomczynski, P., Sacchi, N. (1987) Single-step method of RNA isolation by acid guanidinium thiocyanate-phenol-chloroform extraction. Anal. Biochem. 162, 156-159.

4. Hatsugai, N., Kuroyanagi, M., Yamada, K., Meshi, T., Tsuda, S., Kondo, M., Hara-Nishimura, I. (2004) A plant vacuolar protease, VPE, mediates virus-induced hypersensitive cell death. Science 305, $855-858$.

5. Hayat, Q., Hayat, S., Irfan, M., Ahmad, A. (2010) Effect of exogenous salicylic acid under changing environment: a review. Environ. Exp. Bot. 68, 14-25.

6. Hoeberichts, F. A., Ten Have, A., Woltering, E. J. (2003) A tomato metacaspase gene is upregulated during programmed cell death in Botrytis cinerea-infected leaves. Planta 217, 517-522.

7. Horváth, E., Csiszár, J., Gallé, Á., Poór, P., Szepesi, Á., Tari, I. (2015) Hardening with salicylic acid induces concentration-dependent changes in abscisic acid biosynthesis of tomato under salt stress. J. Plant Physiol. 183, 54-63.

8. Ishikawa, T., Watabane, N., Nagano, M., Kawai-Yamada, M., Lam, E. (2011) Bax inhibitor-1: a highly conserved endoplasmic reticulum-resident cell death suppressor. Cell Death Diff. 18, $1271-1278$ 
9. Jones, J. D., Dangl, J. L. (2006) The plant immune system. Nature 444, 323-329.

10. Kawai-Yamada, M., Ohori, Y., Uchimiya, H. (2004) Dissection of Arabidopsis Bax inhibitor-1 suppressing Bax-, hydrogen peroxide-, and salicylic acid-induced cell death. Plant Cell 16, 21-32.

11. Kim, I., Xu, W., Reed, J. C. (2008) Cell death and endoplasmic reticulum stress: disease relevance and therapeutic opportunities. Nature reviews drug discovery 7, 1013-1030.

12. Livak, K. J., Schmittgen, T. D. (2001) Analysis of relative gene expression data using real-time quantitative PCR and the 2- $\triangle \Delta \mathrm{CT}$ method. Methods 25, 402-408.

13. Lu, S., Faris, J. D., Sherwood, R., Edwards, M. C. (2013) Dimerization and protease resistance: new insight into the function of PR-1. J. Plant Physiol. 170, 105-110.

14. Morris, K., Mackerness, S. A. H., Page, T., John, C. F., Murphy, A. M., Carr, J. P., BuchananWollaston, V. (2000) Salicylic acid has a role in regulating gene expression during leaf senescence. Plant J. 23, 677-685.

15. Pereira, D. A., Ramos, M. V., Souza, D. P., Portela, T. C., Guimarães, J. A., Madeira, S. V., Freitas, C. D. (2010) Digestibility of defense proteins in latex of milkweeds by digestive proteases of Monarch butterflies, Danaus plexippus L.: a potential determinant of plant-herbivore interactions. Plant Sci. 179, 348-355.

16. Poór, P. (2013) Investigation of salt stress- and salicylic acid-induced physiological changes in tomato plants: acclimation or programmed cell death. PhD Thesis, in Hungarian, University of Szeged, Hungary, pp. 61-68.

17. Poór, P., Kovács, J., Szopkó, D., Tari, I. (2013) Ethylene signaling in salt stress- and salicylic acidinduced programmed cell death in tomato suspension cells. Protoplasma 250, 273-284.

18. Poór, P., Borbély, P., Kovács, J., Papp, A., Szepesi, Á., Takács, Z., Tari, I. (2014) Opposite extremes in ethylene/nitric oxide ratio induce cell death in suspension culture and root apices of tomato exposed to salt stress. Acta Biol. Hung. 65, 428-438.

19. Roberts, I. N., Caputo, C., Criado, M. V., Funk, C. (2012) Senescence-associated proteases in plants Physiol. Plant. 145, 130-139.

20. Rossano, R., Larocca, M., Riccio, P. (2011) 2-D zymographic analysis of broccoli (Brassica oleracea L. var. Italica) florets proteases: Follow up of cysteine protease isotypes in the course of post-harvest senescence. J. Plant Physiol. 168, 1517-1525.

21. Sanmartín, M., Jaroszewski, L., Raikhel, N. V., Rojo, E. (2005) Caspases. Regulating death since the origin of life. Plant Physiol. 137, 841-847.

22. Shindo, T., van der Horn, R. A. L. (2008) Papain-like cysteine proteases: key players at molecular battlefields employed by both plants and their invaders. Mol. Plant Pathol. 9, 119-125.

23. Shindo, T., Misas-Villami, J. C., Hörger, A. J., Song, J., van der Horn, R. A. L. (2012) A role in immunity for Arabidopsis cysteine protease RD21, the ortholog of the tomato immune protease C14. PloS ONE 7(1) e29317. doi:10.1371/journal.pone.0029317

24. Singh, M., Bhogal, D., Goel, A., Kumar, A. (2011) Cloning, in silico characterization and interaction of cysteine protease and cystatin for establishing their role in early blight disease in tomato. J. Plant Biochem. Biotech. 20, 110-117.

25. Trobacher, C. P., Senatore, A., Greenwood, J. S. (2006) Masterminds or minions? Cysteine proteinases in plant programmed cell death. This review is one of a selection of papers published in the Special Issue on Plant Cell Biology. Botany 84, 651-667.

26. van Doorn, W. G. (2011) Classes of programmed cell death in plants, compared to those in animals J. Exp. Bot. 62, 4749-4761.

27. Woltering, E. J. (2004) Death proteases come alive. Trends Plant Sci. 9, 469-472.

28. Woltering, E. J. (2010) Death proteases: alive and kicking. Trends Plant Sci. 15, 185-188.

29. Yamada, K., Nishimura, M., Hara-Nishimura, I. (2004) The slow wound-response of $\gamma$ VPE is regulated by endogenous salicylic acid in Arabidopsis. Planta 218, 599-605. 